\title{
Investigation of Female Soccer Players Performance Values Based on Ambient Temperature
}

\author{
Ergün Çakir \\ School of Physical Education and Sports, Kafkas University Sarıkamış Kars, Turkey
}

Copyright $@ 2019$ by authors, all rights reserved. Authors agree that this article remains permanently open access under the terms of the Creative Commons Attribution License 4.0 International License

\begin{abstract}
This study was conducted to determine the changes in ambient temperatures that may occur in some performance values of female soccer players. The research group consisted of 15 female amateur soccer players. (Age: 19,15, Height: 164,12, Body Weight: 54,48, BKI: 19,65). Study performance values of $30 \mathrm{~m}$ sprint speed, $20 \mathrm{~m}$ shuttle run and İllinois test were measured at three different ambient temperatures $\left(-5,5^{\circ} \mathrm{C}, 10,5^{\circ} \mathrm{C}, 30^{\circ} \mathrm{C}\right)$. In the analysis of the data; "SPSS $23^{\prime}$ " package program is used. The distributions of the variables according to the groups were examined and the distributions were parametric by evaluating the normality of the distributions. Repeated Measure ANOVA was used to compare the data obtained at 3 different ambient temperatures from the variables exhibiting parametric properties. In addition, Bofferoni test were performed to determine which groups the difference was in when there were significant differences when the multiple variables were examined. The level of significance in the analyzes was taken as 0.01 and 0.05 . As the temperature values increased, all the measured parameters showed significant changes compared to the measurements in the cold environment and there was a significant difference in the performance values $(p<0.05)$.As a result; as the temperature values increased, all the measured parameters were significantly different from the measurements in the cold environment. It is seen that high efficiency is obtained in all sporting activities in hot environment and as a result the performance of the athletes is increased according to environment temperature $\left(-5,5^{\circ} \mathrm{C}\right.$ to $\left.30^{\circ} \mathrm{C}\right)$.
\end{abstract}

Keywords Temperature, Performance, Motoric Feature

\section{Introduction}

We can list the factors that affect performance in sports as internal and external factors. Since it is quite difficult to objectify internal factors, it is almost impossible to calculate the effects of these factors on performance and fully anticipate the changes that can be made. External factors, as the name implies, are factors that do not originate from the body and structure of the human body, and that affect sports performance indirectly from outside through a physical or psychic component. We can influence external factors more than internal factors. It is possible to replace and improve most of the external factors with appropriate conditions and interventions. Among the external factors that are more than internal ones, we can also list heat, warming and climate [1].

Hot and cold temperatures are environmental factors that affect the physiological responses of exercise. These factors bring about changes in the ability of the body to protect its speed and power. To put it more simply, performance in cool climates is often better than performance in cold or hot environments [2].

Speed, agility and aerobic endurance are considered to be important skills that influence performance in many sports. These abilities are closely related to the performance of the athletes and are influenced by external factors to a great extent. Some researchers think that training in hot environment before a sports competition which will take place in cold environment or vice versa will have a negative impact on the athlete's performance [2, 3].

It is possible to control the tolerance of the human body to hot and cold temperature and by certain mechanisms. Body heat does not rise in a dry and steamy environment $\left(50-55^{\circ} \mathrm{C}\right)$; internal heat is kept constant through evaporation. However, if the environment is $100 \%$ humidified, body temperature starts to increase as soon as the ambient temperature rises above $35^{\circ} \mathrm{C}$. The internal temperature, which is around $37^{\circ} \mathrm{C}$, can go up to $40^{\circ} \mathrm{C}$ during exercise. At this temperature, the organism affects the functioning of hormonal and enzymatic activities negatively. Thermoregulation is provided both while exercising, or when the heat arising due to the increase in metabolic activity from the part of the body where it is high (from the tissue) to other tissues transfers through blood flow [4]. In situations where the organism faces cold 
temperatures, the body's internal heat may be reduced. Performance is adversely affected when the temperature reaches $35^{\circ} \mathrm{C}$. Such situations do not only deteriorate the sporting performance, but also threaten life. To eliminate this unfavorable situation, the organism generates more metabolic energy and heat as a defense mechanism, skin contracts veins and control vital activities by reducing sweating $[5,6]$.

\section{Materials and Methods}

\section{Study Group}

15 female football players who play football at amateur level participated in this study. Measurements were made at three different temperatures $\left(-5.5^{\circ} \mathrm{C}, 10.5^{\circ} \mathrm{C}, 30^{\circ} \mathrm{C}\right)$. To obtain a temperature value of $-5.5^{\circ} \mathrm{C}$ and $10.5{ }^{\circ} \mathrm{C}$, the temperature of the room where the measurement would be performed was kept under control by air conditioning. For the temperature of $30{ }^{\circ} \mathrm{C}$, the measurements were carried out at the appropriate temperature during the day. The study group was informed about the study and was asked to complete a form indicating that they voluntarily participated in the research.

\section{Data Collection}

\section{Body Composition}

One day prior to the measurements, the athletes' height and body weights were measured with the Seca brand height and weight measuring instrument. The heights of the athletes were measured on naked feet; they wore only shorts while their body weights were measured. Bio electrical Impedance (Tanita Body Fat Analyser, Model TBF 300) was used in determining the body fat percentages of the athletes.

\section{Aerobic Capacity Measurement}

This measurement was made with the aim of determining the cardio respiratory fitness levels of the athletes. With the help of the strips, the starting and finishing points of $20 \mathrm{~m}$ were determined and the signal generator was set. The athletes were asked to step on the $20 \mathrm{~m}$ line with the signal and to run forward and backward with the recorded signals. The running start speed was 8.5 $\mathrm{km} / \mathrm{h}$, increased by $0.5 \mathrm{~km} / \mathrm{s}$ in each minute. The test was terminated when the athlete could not follow the signal voice. The last number at maximal velocity was regarded to be the max $\mathrm{VO}_{2}$ index. [7].

\section{$30 \mathrm{~m}$ Speed Test}

After goal-specific warming, subjects were waited on stand-by and when they felt ready, they ran with maximum speed. Time in the $30 \mathrm{~m}$ speed test was determined by New Test 2000 Powertimer device [7].

\section{Illinois Agility Test}

It was applied to determine the subject's coordination and agility. A test course with a width of $5 \mathrm{~m}$, length of 10 $\mathrm{m}$ that consists of three cones in the middle section lined up on a straight line $3.3 \mathrm{~m}$ apart from each other. The test consists of slalom run that includes $40 \mathrm{~m}$ straight and $20 \mathrm{~m}$ slalom running between the cones. $180^{\circ}$ turns every $10 \mathrm{~m}$. After the preparation of the test course, double door photocell electronic chronometer system with 0.01 sensitivity was placed at the beginning and the end of the course. The finish time was recorded in seconds. The test was repeated 2 times with full rest and the best score was recorded [7].

\section{Data Analysis}

"SPSS 23" package program was used in the data analysis. Descriptive statistics of age, height, and body weight and body mass index values of participants were calculated. The distribution of variables by groups was examined; the test made to show whether the data are suitable for normal distribution showed that the distributions showed parametric properties. Repeated measure ANOVA test was used to compare the data obtained at 3 different ambient temperatures from the variables with parametric properties. Furthermore, when multiple variables were examined, there was a significant difference between some of them; to determine between which groups this difference is, Bonferroni test was performed. The level of significance was set as 0.01 and 0.05 in the analysis. 


\section{Results}

Table 1. Physical parameters of the subjects participating in the study

\begin{tabular}{cccccc}
\hline & N & Minimum & Maximum & Average & Standard Deviation \\
\hline Age & 15 & 17 & 21 & 19,15 & 2,11 \\
\hline Height (cm) & 15 & 157 & 171 & 164,12 & 3,61 \\
\hline Body Weight (kg) & 15 & 47,5 & 60,3 & 54,48 & 4,17 \\
\hline BMI (kg/height $\left.{ }^{2}\right)$ & 15 & 17,4 & 22,7 & 19,65 & 1,72 \\
\hline
\end{tabular}

Age, height, body weight, mean BMI of the participants were 19.15 years, $164.12 \mathrm{~cm}, 54.48 \mathrm{~kg}$ and $19.65 \mathrm{~kg} / \mathrm{cm}^{2}$, respectively.

Table 2. Repeated ANOVA results of the subjects according to variables

\begin{tabular}{|c|c|c|c|c|c|c|}
\hline & \multicolumn{6}{|c|}{$\mathrm{N}:(\mathbf{1 5})$} \\
\hline & Temperature & $\bar{X}$ & ss & $\mathbf{F}$ & $\mathbf{p}$ & Difference $^{* * *}$ \\
\hline \multirow{3}{*}{$\begin{array}{c}\text { Shuttle Run } \\
\text { (Aerobic Capacity) } \\
\text { (ml/kg/min) }\end{array}$} & $-5,5$ & 47.90 & 6.168 & \multirow{3}{*}{7.277} & \multirow{3}{*}{$0.000^{* * *}$} & \multirow{3}{*}{$\begin{array}{c}-5,5^{\circ} \mathrm{C}<10,5^{\circ} \mathrm{C} \\
10,5^{\circ} \mathrm{C}>30^{\circ} \mathrm{C}\end{array}$} \\
\hline & 10,5 & 58.36 & 5.286 & & & \\
\hline & 30 & 53.45 & 4.223 & & & \\
\hline \multirow{3}{*}{$\begin{array}{c}\text { Sprint } \\
\text { (30m Speed) } \\
\text { (min.) }\end{array}$} & $-5,5$ & 5.54 & 0.244 & \multirow{3}{*}{37.845} & \multirow{3}{*}{$0.000^{* * *}$} & \multirow{3}{*}{$\begin{array}{c}-5.5^{\circ} \mathrm{C}>10,5^{\circ} \mathrm{C}, 30^{\circ} \mathrm{C} \\
10.5^{\circ} \mathrm{C}>30^{\circ} \mathrm{C}\end{array}$} \\
\hline & 10,5 & 5.33 & 0.213 & & & \\
\hline & 30 & 5.25 & 0.191 & & & \\
\hline \multirow{3}{*}{$\begin{array}{l}\text { Agility Coordination } \\
\text { (sec.) }\end{array}$} & $-5,5$ & 17.88 & 0.785 & \multirow{3}{*}{7.506} & \multirow{3}{*}{$0.000^{* * *}$} & \multirow{3}{*}{$\begin{array}{c}-5,5^{\circ} \mathrm{C}>10,5^{\circ} \mathrm{C} \\
30^{\circ} \mathrm{C}<10,5^{\circ} \mathrm{C}\end{array}$} \\
\hline & 10,5 & 17.60 & 0.695 & & & \\
\hline & 30 & 17.43 & 0.68 & & & \\
\hline
\end{tabular}

${ }^{*} \mathrm{p}<0.05 * * \mathrm{p}<0.01 * * *$ Bonferroni Test

Results of Repeated ANOVA for testing shuttle run (aerobic endurance), sprint and agility values in different ambient temperatures showed that there was a statistically significant difference in sprint, shuttle run (aerobic endurance) and agility values [( $\mathrm{F}=7.27 ; \mathrm{p}<0.01)$, $(\mathrm{F}=37.84$; $\mathrm{p}<0.01),(\mathrm{F}=7.50 ; \mathrm{p}<0.01)]$. The results of the Bonferroni test conducted to find out what ambient temperature this difference is caused by revealed that for the sprint variable, running duration of the subjects decreased as the temperature was changed from cold to warm at $30 \mathrm{~m}$; aerobic capacity decreased at $-5.5^{\circ} \mathrm{C}$, increased at $10.5^{\circ} \mathrm{C}$ and decreased at $30^{\circ} \mathrm{C}$; agility duration, another performance value, decreased with the transition from cold temperature to hot temperature (Table 2).

\section{Conclusions}

Too hot or too cold exercise environments reduce performance and affects performance negatively. Research shows that long exercises at temperatures above $15.5^{\circ} \mathrm{C}$ can have a reducing effect on the performance when compared to exercises between $4.5^{\circ} \mathrm{C}$ and $15.5^{\circ} \mathrm{C}$. Cold environment, on the other hand, makes it difficult to maintain the body temperature; when the core temperature falls below normal, fewer motor units in the muscle participate in the activity and the contraction rate of muscle cells participating in the activity is also reduced [2].

This research has examined the performance changes that occurred in female football players due to ambient temperature. The results of the test conducted for this purpose revealed that there were significant differences in sprint (30 m sprint), shuttle run (aerobic endurance) and agility values at three different ambient temperatures ( $\mathrm{p}$ $<0.05$ ).

A study by Chen et al [8] concluded that cardiovascular compliance improves, blood flow accelerates and heart rate decreases at certain rates if the temperature is adjusted. Another study found that metabolism's reaction to cold weather is increasing blood pressure and heart rate [9, 2]. For physical exercise, the physiological adaptation of the respiratory system, which will meet the increasing oxygen need, is very important. This adaptation depends on factors such as the increase in respiratory parameters, development of respiratory muscles, the expansion ability of the lungs and the thorax and the elasticity of the bronchi and bronchi-oles [10, 11, 12]. Roberts [13] reported that in exercises performed in a cold environment, if the athlete cannot maintain the internal temperature constant, there will be a decrease in their performance, and that $1^{\circ} \mathrm{C}$ decrease in core temperature will decrease the aerobic capacity by $5-6 \%$. Study carried out at different ambient temperatures revealed that the capacity to use oxygen (aerobic power) increased in parallel with the increase in ambient temperature. When the atmospheric air reaches the trachea in a cold environment, the air moistens more when compared to the air in the hot environment and $\mathrm{PO}_{2}$ pressure falls, thus, it becomes more difficult for oxygen to 
mix with blood in a cold environment, affecting performance adversely. Certain studies have shown that oxygen consumption is higher and the accumulation of lactic acid is less during exercise in a hot environment when compared to cold environment [4]. In another study, maximal exercise period was applied to male athletes at different temperatures $\left(20^{\circ} \mathrm{C}\right.$ and $\left.-12^{\circ} \mathrm{C}\right)$ on the bicycle; the study concluded that max $\mathrm{VO}_{2}$ was much higher at $20^{\circ}$ $C$ than at $-12^{\circ} \mathrm{C}$ [14]. Nimmo [15] argued that if the exercise is carried out over a long period of time and at an average density, the ambient temperature on average between $11^{\circ} \mathrm{C}$ and $15^{\circ} \mathrm{C}$ may be advantageous, and that hotter or colder ambient temperature can damage performance. A study carried out with bicycle athletes revealed that as a result of aerobic power programs applied at two different temperatures $\left(13^{\circ} \mathrm{C}\right.$ and $\left.38^{\circ} \mathrm{C}\right)$, endurance levels of the athletes increased after the athletes adapted to hot environment. Considering the effort pulse variable, it was found that heart rate is higher though the running distance is less in the environment with reduced temperature $\left(-11^{\circ} \mathrm{C}\right)$. Based on this result, we can conclude that fatigue threshold falls in cold weather $[16,17]$.

Based on the test results, we can say that the $30 \mathrm{~m}$ sprint speed improved as the ambient temperature increased. A study on athletes from different branches at five different ambient temperatures determined that parallel to the increase in the ambient temperature, athletes ran $30 \mathrm{~m}$ distance in a shorter time [10]. An application of $30 \mathrm{~m}$ sprint applied to eight healthy men at different ambient temperatures showed that the sprint force generated at $30^{\circ}$ $\mathrm{C}$ is greater than the sprint force generated at $19^{\circ} \mathrm{C}$ [18]. Another study examining the performance values at ambient temperature concluded that fast-contracting tendons produce less power at low temperatures than slow-contracting tendons [19]. According to Bergh and Ekblom [20], an increase in speed performance is observed due to the increase in muscle temperature in the transition from cold to hot environment. According to Oksa et al [21], cold environment significantly reduces muscle power. Another study [22] found that there is an increase in the muscle strength of male athletes parallel to the increase in temperature at different times and temperatures during the day and that in the event of a decrease in temperature, muscles produce less power and, consequently, physical performance is negatively affected.

We can argue that an increase in ambient temperature results in an increase in the agility parameter. It has been observed that muscles produce less power, are stimulated more slowly, and muscle coordination is reduced accordingly at lower temperatures $[5,10]$. A study by Ünal [23], lists the changes that take place in the organism during exercises in cold environment as follows: muscular tone and viscosity increases, duration of muscle contraction and relaxation of antagonist muscles lengthens out, nerve conduction slows down, reflex response time grows longer, skill, coordination and agility deteriorates, thus, athletes' condition decreases. Another study carried out in a cold environment determined that there is a decrease in agility performance and muscle coordination in the exercises in cold environment [13]. In another study about environmental temperature on physiological responses and endurance exercise capacity during submaximal and maximal exercises in 9 soccer players. They cycled for 20 minutes at $60 \%$ maximum oxygen uptake (60\% VO2max), and then exercise intensity was increased at a rate of $0.5 \mathrm{kp} / 2$ min until exhaustion at three different environmental conditions. They found that, physiological responses and endurance exercise capacity are impaired under cool or hot conditions compared with moderate conditions [22]. So, environmental temperature conditions play an important role for exercise performance like our study.

In conclusion, as the temperature values increase, significant differences occur in all the measured parameters compared to the measurements in the cold environment. High performance is achieved in all sports activities in hot environment and athletes' performances increase in parallel to an increase in the ambient temperature $\left(-5.5^{\circ} \mathrm{C}\right.$ to $\left.30^{\circ} \mathrm{C}\right)$. These results indicate that athletes should do adaptation exercise to the hot and cold environment to eliminate the adverse effects of ambient temperature and to improve their performances in an appropriate manner in all weather conditions.

\section{REFERENCES}

[1] Bayraktar B, Kurtoğlu M. (2004), Sporda performans ve performans artırma yöntemleri. Atasü T, Yücesir İ, eds. Doping ve futbolda performans artırma yöntemleri, İstanbul. 269-296.

[2] Murray, B., kenney, L.W. (2016) Practical guide to exercise physiology. İncludes index. ISBN: 978-1-4504-6180-1

[3] Dehnert C, Hutler M, Liu Y, et al. (2002), Erythropoiesis and performance after two weeks of living high and training low in well trained triathletes. Int $\mathrm{J}$ Sports Med.; 23(8):561-6.

[4] Günay, M., Cicioğlu, İ., Kara, E., (2006), Egzersize metabolik ve 1 sı adaptasyonu. Ankara: Gazi Kitapevi.

[5] Sawka, M. N., \& Young, A. J. (2006). Physiological systems and their responses to conditions of heat and cold (No. MISC-03-12). Army research inst of environmental medicine natıck ma thermal and mountain medicine division.

[6] Zorba, E. (2004). Yaşam boyu spor. Marmara Basım Yayım, Istanbul.

[7] Michael, P.R., Robert, C.M. (2009). Functional testing in human performance. Human kinetics. ISBN: 9-780-7360-6879-6

[8] Roberts, W.O., (2001). Cold-related injury in athletes and 
active people, Principles And Practice Of Primery Care Sports Medicine, Ed. By Carrett WE, Kirkandall DT, Philadelphia.

[9] Mor, A., İpekoğlu, G., Arslanoglu, C., Acar, K., \& Arslanoglu, E. (2017). The Effects of Electrostimulation and Core Exercises on Recovery After High-Intensity Exercise. International Journal of Applied Exercise Physiology, 6(4), 46-53.

[10] Çakir, E., Yüksek, S., Asma, B., \& Arslanoglu, E. (2016). Effects of Different Environment Temperatures on Some Motor Characteristics and Muscle Strength. International Journal of Environmental and Science Education, 11(10), 3985-3993.

[11] Çakır, E., Şenel, Ö. (2017). Effect of cold water immersıon on performance. European Journal of Physical Education and Sport Science. 3 (12): 419-428

[12] Gözü, R.D., Liman, E., Kan, İ., (1988), Thoraks ölçümleri ve solunum fonksiyonlarının antrenmanlarla değişimi. Spor Hekimliği Dergisi, 23 (1), 1-8.

[13] Roberts, W.O., (2005). Another viewpoint on exertional heatstroke. Phys. and Sportsmed. 33 (10): 42-49

[14] Lindberg, AS., Malm, C., Hammarström, D., Oksa, J., Tonkonogi, M. (2012), Maximal work capacity and performance depends warm-up procedure and environmental but not inspired air temperatures. Journal of Exercise Physiology., Volüme 15 Number 1.

[15] Nimno, M. (2004), Exercise in cold. Journal of Sports Sciences, 22: 898-916

[16] Zhao, J., Lorenzo, S., An, A., Feng, W., Lai, L. Cui, S. (2013). Effects of heat and different humidity levels on aerobic and anaerobic exercise performance in athletes. Journal of Exercise Science \& Fitness 11 (2013) 35-41

[17] Lorenzo, S., Halliwill, JR., Sawka, MN., Minson, CT. (2010), Heat acclimation improves exercise performance. J Appl Physiol. 109(4):1140-1147.

[18] Ball, D., Burrows, C., Sargeant, AJ. (1999), Human power output during repeated sprint cycle exercise: The influence of thermal stress. Eur J Appl Physiol Occup Physiol 79: 360-366

[19] Radamaker, A. (1997) Human locomotory performance: effect of fatigue and temperature in relation to muscle fibre type variability. PhD Thesis, Vrije University Amsterdam. Pp 73-93

[20] Bergh, U., Ekblom, B. (1979), Influence of muscle temperature on maximal muscle strength and power output in human skeletal muscles. Acta Physiol Scand 107: 33-37

[21] Oksa J, Rintamäki H, Rissanen S, Rytky S, Tolonen U, Komi PV (2000), Stretch- and H-reflexes of the lower leg during whole body cooling and local warming. Aviat Space Environ Med 71,2: 156-161

[22] Racinais, S., Blonc, S., Jonville, S., Hue, O. (2005) Time-of-day influences the environmental effects on muscle force and contractility. Med Sci Sports Exerc 37: 256-261

[23] Ünal, M., (2002). Sicak ve soğuk ortamda egzersiz. İstanbul Üniversitesi Tıp Fakültesi Mecmuası, İstanbul. 65:4.
[24] No, MiHyun, Kwak Hyo-Bum. (2016) Effects of environmental temperature on physiological responses during submaximal and maximal exercises in soccer players. Integrative Medicine Research. Volume 5:3, 216-222. 